\title{
RISKS TO STOCKS OF NATIVE TROUT OF THE GENUS SALMO (ACTINOPTERYGII: SALMONIFORMES: SALMONIDAE) OF SERBIA AND MANAGEMENT FOR THEIR RECOVERY
}

\author{
Predrag SIMONOVIĆ ${ }^{*}$, Zoran VIDOVIĆ ${ }^{2}$, Ana TOŠIĆ ${ }^{1}$, Dubravka ŠKRABA ${ }^{1}$, \\ Jelena ČANAK-ATLAGIĆ ${ }^{1}$, and Vera NIKOLIĆ ${ }^{1}$ \\ ${ }^{1}$ University of Belgrade, Faculty of Biology, Belgrade, Serbia \\ ${ }^{2}$ University of Belgrade, Teacher Education Faculty, Belgrade, Serbia
}

\begin{abstract}
Simonović P., Vidović Z., Tošić A., Škraba D., Čanak-Atlagić J., Nikolić V. 2015. Risks to stocks of native trout of the genus Salmo (Actinopterygii: Salmoniformes: Salmonidae) of Serbia and management for their recovery. Acta Ichthyol. Piscat. 45 (2): 161-173.
\end{abstract}

Background. Insufficiently controlled stocking compromises the high diversity of wild trout stocks of Serbia. Native brown trout, Salmo cf. trutta Linnaeus, 1758, and Macedonian trout, Salmo macedonicus (Karaman, 1924), reveal remarkable diversity assessed using the mtDNA molecular markers, with the eight exclusive and several more widely spread haplotypes found in them. Four alien trout species and strains and one strain of Macedonian trout were introduced into the home areas of the native wild trout stocks in Serbia. In addition to them, wild trout stocks were also affected by farmed rainbow trout, Oncorhynchus mykiss (Walbaum, 1792), and brook trout Salvelinus fontinalis (Mitchill, 1815), that regularly escape to streams, and from Ohrid trout, Salmo letnica (Karaman, 1924), and Arctic charr, Salvelinus alpinus (Linnaeus, 1758), stocked into streams and reservoirs. Risk of invasiveness that wild trout stocks are exposed to and their restoration were driving forces for this study.

Materials and methods. Trout specimens from the Jerma River sampled in 2013 were additionally analysed for their mtDNA haplotype. The invasiveness potential of eleven alien trout species and strains introduced by stocking into wild brown- and Macedonian trout stocks in Serbia were assessed with the Fish Invasiveness Screening Kit (FISK).

Results. Five of introduced trout species and strains were classified as having a high risk (sensu lato) and two of them as having a high risk (sensu stricto) of being (or becoming) invasive.

Conclusion. Progressively rising and insufficiently controlled fishing and management with stocking of non-indigenous trout in wild brown trout stocks are the main current threats to the original diversity. Alien brown trout strains cross breed with native brown trout and incorporate into their stocks. Currently, feral rainbow-, brook-, and Ohrid trout reveal great invasive potential by naturalization in waters heavily stocked with them. The fisheries measures aiming to control and/or to eradicate alien strains of brown trout involve the restriction of stocking, landing of trout suspected as of alien strain or species, as well as the stringent control of stocking material used for the restorative stocking. They are mandatory, regarding the conservational dependence of wild brown trout stocks.

Keywords: fish, wild trout, hatchery strains, stocking, invasiveness, FISK, conservation, fisheries management

\section{INTRODUCTION}

In the last ten years, the investigation of wild brown trout Salmo cf. trutta Linnaeus, 1758 stocks in Serbia (Fig. 1) has indicated high diversity in the watersheds of all three seas occurring in the region (Black-, Aegean-, and Adriatic seas). Marić et al. (2004) reported for the first time the occurrence of Macedonian trout, Salmo macedonicus (Karaman, 1924), as a native species in tributaries of the Dragovištica River (i.e., Struma River drainage area of the Aegean Sea basin). Three main clusters of Salmo stocks appeared morphologically distinct and this finding was consistent across their dispersal area (Simonović et al. 2005). Phylogenetic analysis (Simonović et al. 2007) confirmed the natural character of stocks by resolving them as clades including brown trout from the Velika Morava River drainage area and Macedonian trout from the Aegean Sea drainage area. A distinct clade including Zeta trout, Salmo cf. taleri (Karaman, 1933), from the Gradac Stream (a tributary of the Kolubara River in the Sava River drainage area in western Serbia, Black Sea basin) comprised also Atlantic brown trout, Salmo trutta, which has hitherto been introduced into Serbia for stocking purposes. Phylogenetic rela- 
tions reconstructed based on morphological characters were concordant across the majority of clades with those inferred using control region (D-loop) mtDNA analysis (Marić et al. 2006 b), which proved to be a useful marker in the assessment of the molecular diversity of brown trout stocks. According to this molecular marker, Bernatchez et al. (1992) defined five main evolutionary lineages of brown trout: the Danubian (Da), Atlantic (At), Adriatic (Ad), Mediterranean (Me), and the marmoratus (Ma). Brown trout in streams of Serbia were found to belong to three of those lineages: Da, $\mathrm{Ad}$, and At, each having several variants (haplotypes). In addition to the widespread native (Da1, Adcs1, and Adcs11) and introduced (Da2, Atcs1) mtDNA haplotypes, several new, native haplotypes were discovered in all three drainage areas of Southern Serbia (Marić et al. 2006a, Tošić et al. 2014). Some of them (Da-Vr, Da-Dž, and Ad-Bož) were found to be intermediate between the Danubian (Da) and Adriatic (Ad) lineages (after Bernatchez et al. 1992). Also, new and/or drainage-specific, native haplotypes of more advanced origin (Da-Vl, Ad-Ti, Ad-Prz, and Ad-Pe) of wild brown trout were recorded in south-western Serbia (Vlasina River), southern Kosovo (Tisova and Erenik rivers), and in the Metochia (Pećka and Prizrenska Bistrica rivers) (Marić et al. 2006a). Likewise, the tentatively vicariant Da-s6 (Genbank accession code U18202) and Da22 haplotypes, which were so far known only from the Caspian Sea drainage area of Iran (Bernatchez 2001) and upper Danube River basin in Austria (Duftner et al. 2003), respectively, were reported for the Studenačka and Rosomačka rivers in south-eastern Serbia. Finally, the last discovered native mtDNA haplotype of wild brown trout was Da23c, which Tošić et al. (2014) reported as exclusive for eastern Serbia.
The exclusive occurrence of trout species of non-indigenous haplotypes in specific streams out of their native dispersal area (e.g., Adriatic trout, Salmo farioides Karaman, 1938, of the Ad-Prz mtDNA haplotype in the Tripušnica River, Vardar drainage area; Macedonian trout of the Adcs 1 haplotype in the Jerma River, Velika Morava drainage area) (Table 1), points to the occurrence of stocking events into either hitherto pristine streams (i.e., free of wild brown trout), or streams holding wild brown trout of the Danubian lineage, respectively. Also, Macedonian trout was reportedly stocked into the Jerma River about 15 years ago (Marić et al. 2006a), Lake Ohrid trout, Salmo letnica (Karaman, 1924), was heavily and repeatedly stocked from a hatchery into the Vlasina Lake in Southern Serbia in 1950s and 1960s for commercial fishing purposes (Janković and Raspopović 1960).

In addition to translocated trout species and strains, alien North American rainbow trout, Oncorhynchus mykiss (Walbaum, 1792), and brook trout, Salvelinus fontinalis (Mitchill, 1814), north European Arctic charr, Salvelinus alpinus (Linnaeus, 1758), and the west-European Atlantic strain of brown trout, Salmo trutta, of the Atcs1 mtDNA haplotype were also introduced into streams of Serbia by stocking from hatcheries. Simonović et al. (2013) provided an assessment of their invasiveness potential in the Balkans.

This paper aims to assess the susceptibility of wild trout stocks holding native trout species to the potential risk posed by the introduction of alien trout species and strains into the streams in Serbia. To this end, FISK screening kit (Copp et al. 2005) was employed to estimate the invasiveness potential of alien trout species and strains listed as stocking material in Serbia (but also in the broader Balkans region). By assessing stocking as a

Table 1

Alien haplotype proportions of resident trout in selected streams of Serbia

\begin{tabular}{|c|c|c|c|c|c|c|c|}
\hline Stream & $n$ & $\begin{array}{l}\text { Native } \\
\text { species }\end{array}$ & $\begin{array}{c}\text { Native } \\
\text { haplotype }\end{array}$ & $\begin{array}{l}\text { Introduced } \\
\text { species }\end{array}$ & $\begin{array}{l}\text { Introduced } \\
\text { haplotype }\end{array}$ & $\mathrm{A} \%$ & References \\
\hline Rečka & 3 & S. cf. trutta & Da23c & S. cf. trutta & Da1 & 33 & Marić et al. 2006b \\
\hline Crni Timok & 26 & S. cf. trutta & $\mathrm{Da} 23 \mathrm{c}$ & S. cf. trutta & Da2 & 48 & Tošić et al. 2014 \\
\hline Gradac & 3 & S. cf. taleri & Da1 & S. cf. trutta & $\mathrm{Da} 2$ & 33 & Marić et al. 2006b \\
\hline Zmajevac & 3 & S. cf. taleri & Da1 & S. cf. trutta & $\mathrm{Da} 2$ & 66 & Marić et al. 2006b \\
\hline Resava & 2 & S. cf. trutta & Da1 & S. cf. trutta & $\mathrm{Da} 2$ & 50 & Marić et al. 2006b \\
\hline Gradac & 3 & S. cf. taleri & Da1 & S. trutta & Atcs1 & 33 & Marić et al. 2006b \\
\hline Gradac & 3 & S. cf. taleri & Dal & S. trutta & Atcs1 & 33 & Simonović et al. 2014 \\
\hline Rosomačka & 3 & S. cf. trutta & Da1 & S. cf. taleri & $\mathrm{Da} 22$ & 33 & Marić et al. 2006b \\
\hline Vrla & 3 & S. cf. trutta & $\mathrm{Da}-\mathrm{Vr}$ & S. macedonicus & Adcs1 & 33 & Marić et al. 2006b \\
\hline Lisina & 2 & S. macedonicus & Ad-Bož & S. macedonicus & Adcs1 & 50 & Marić et al. 2006b \\
\hline Dejan & 3 & S. macedonicus & Ad-Bož & S. macedonicus & Ades1 & 33 & Marić et al. 2006b \\
\hline Brankovačka & 2 & S. macedonicus & Ad-Bož & S. trutta & Atcs 1 & 50 & Marić et al. 2006b \\
\hline Pećka & 8 & S. farioides & Ad-Pe & S. farioides & Adcs11 & 50 & Marić et al. 2006b \\
\hline Tripušnica & 5 & - & - & S. farioides & Ad-Prz & 100 & Marić et al. 2006b \\
\hline Jerma & 4 & S. cf. trutta & Da1 & S. macedonicus & Adcs1 & 100 & Marić et al. 2006b \\
\hline Jerma & 4 & S. cf. trutta & Da1 & S. macedonicus & Adcs1 & 100 & Simonović unpublished \\
\hline Jerma & 11 & S. cf. trutta & Da1 & S. macedonicus & Ades 1 & 36 & This study \\
\hline Jerma & & S. cf. trutta & Da1 & S. trutta & Atcs 1 & 27 & This study \\
\hline Jerma & & S. cf. trutta & Da1 & S. cf. taleri & $\mathrm{Da} 22$ & 9 & This study \\
\hline
\end{tabular}

$n=$ number of analysed fish in a sample, A\% percentage of trout with alien haplotype in the wild stock. 
vector of introduction of alien species and strains into recipient waters and surveying how their native climate and habitat features could match those of the recipient area, management options are proposed for the streams holding wild brown trout. Disengagement of stocking and very exceptional restorative stocking with the hatchery material originating from the locally adapted, domesticated brown trout strains as management options opposite to the current fishery practice are proposed. They are to improve the current status, both fishery and conservational, of wild trout stocks that hold indigenous trout.

\section{MATERIALS AND METHODS}

Eleven trout species and strains alien to the recipient brown trout streams of Serbia were assessed from their recently recorded and previously known dispersal areas. Trout species and strains originating from distant zoogeographic regions (e.g., rainbow trout, brook trout,

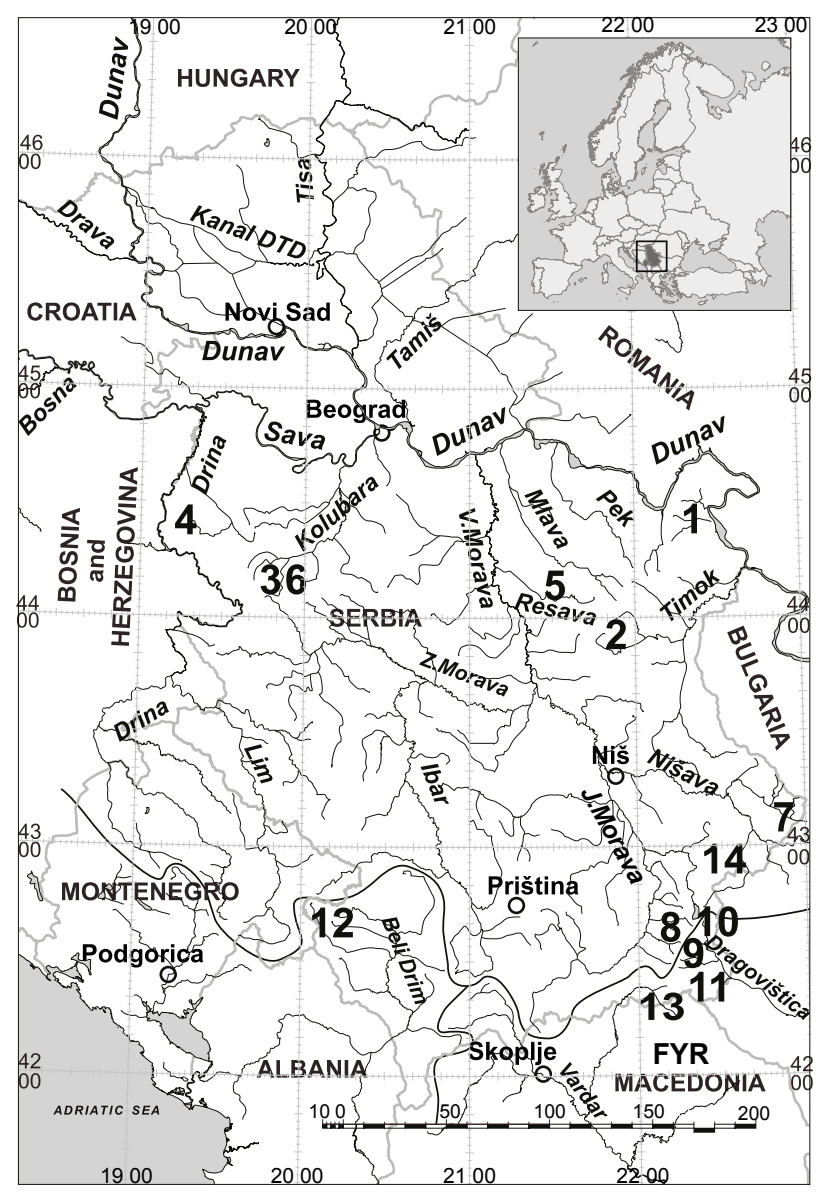

Fig. 1. Localities in Serbia, where original mtDNA haplotypes in wild brown trout were recorded together with those introduced by stocking; 1 = Rečka Stream, 2 = Crni Timok River, 3 and $6=$ Gradac River, $4=$ Zmajevac Stream, $5=$ Resava River, $7=$ Rosomačka Stream, $8=$ Vrla River, $9=$ Lisina River, $10=$ Dejan Stream, 11 = Brankovačka River, $12=$ Pećka River, 13 = Tripušnica Stream, 14 = Jerma River; Solid black line close to the bottom of the map delimits Black Sea (north), Adriatic Sea (south-western) and Aegean Sea (south-eastern) drainage areas
Arctic charr, and the Atlantic strain of brown trout) were considered to be introduced following Richardson et al. (2000), whose definitions were used throughout the presently reported study. Species native to and introduced from streams of the Balkans area (e.g., of Da1, Da2, and Da22 haplotypes of brown trout; Adcs11 and Ad-Prz of Adriatic trout; Adcs1Macedonian trout; and Ohrid trout of unknown haplotype) were regarded as translocated. The proportion of trout holding alien haplotypes for each stream (Table 1) was calculated from records of genotyping (Marić et al. 2006a, Tošić et al. 2014) and from records for the Jerma River as provided in the presently reported study. Eleven trout individuals from the Jerma River sampled in 2013 by fly fishing were additionally analysed for their mtDNA haplotype using the methodology for DNA extraction and D-loop amplification described in Tošić et al. (2014). The amplified D-loop region of the mtDNA was analysed using AluI and SatI endonucleases. AluI cuts DNA exclusively between AG and CT in a sequence. In trout of Adriatic lineage, AluI cuts D-loop at three places, producing four segments (of lengths of 563, 464, 37, and $4 \mathrm{bp}$ ) that show two bands of appropriate position in the run (notably, the last two fragments are too small for visualization on gel). In trout of Danubian lineage, the same endonuclease cuts D-loop at four places, producing five segments (of lengths 464, $311,252,37$, and $4 \mathrm{bp}$ ) that display as three bands. SatI endonuclease cuts DNA only between GC and NGC in a sequence. In brown trout of Atlantic lineage, it cuts D-loop at one place and gives two fragments (390 and $690 \mathrm{bp}$ ), whereas in brown trout of Danubian lineage it does not cut D-loop and the whole D-loop of $1080 \mathrm{bp}$ is visualized on the gel. Amplified D-loop of each fish in the sample was sequenced in Macrogen Inc. (Order number 141014FN-168).

The potential impact of non-native trout species and strains to the native brown trout stocks was assessed using the FISK (Fish Invasiveness Screening Kit) protocol originally developed for the UK by Copp et al. (2005). This protocol consists of 49 questions about life-history traits in two sections. Thirteen questions are related to alien fish species biogeography and history of introduction, and 36 questions to their biology and ecology. All questions are grouped into categories related to certain sectors most likely to be affected by invasive alien fish species. The 'aquacultural/fisheries' and 'environmental' categories contain eight questions each, the 'nuisance' category contains two questions, and category 'combined' contains 31 questions shared with the categories 'aquacultural/fisheries' and 'environmental'. Scoring below the zero value assigns the "no invasiveness" status, whereas the positive values determine alien species as invasive with the low, medium, or high risk of invasiveness. The lowest possible score is -15 and the highest possible score is 57 (Lorenzo Vilizzi personal communication).

Species and strains of trout were classified a priori as either invasive or non-invasive (Table 2) following assignment in the Invasive Species Specialist Group database ${ }^{*}$ and 
FishBase (Froese and Pauly 2014). For translocated trout species across the region (i.e., Macedonian-, Ohrid-, and brown trout), the a priori assignment used in Simonović et al. (2013) was followed. Because classification of invasiveness for brown trout strains of the Danubian lineage was not available, they were categorized a priori as invasive. The a priori invasiveness assignment was accomplished for computation of Receiver Operating Characteristic (ROC) curve analysis (Bewick et al. 2004), and the conservation status available for particular trout species was followed from IUCN (Anonymous 2014b). All eleven trout species and strains were assessed by the first author (PS).

ROC analysis served to assess the predictive ability of FISK to discriminate between invasive and non-invasive species (Copp et al. 2009). Statistically, a ROC curve is a graph of sensitivity vs. 1- specificity or, alternatively, sensitivity vs. specificity), where in the present context sensitivity and specificity will be the proportion of invasive and non-invasive fish species, respectively, that are correctly identified by the FISK tool as such. A measure of the accuracy of the calibration analysis is the Area Under the ROC Curve (AUC). If the AUC is equal to 1.0 (i.e., the ROC 'curve' consists of two straight lines, one vertical from 0.0 to 0.1 and the other horizontal from 0.1 to 1.1 ), then the test is $100 \%$ accurate because both sensitivity and specificity are 1.0 and there are neither false positives (i.e., non-invasive species categorized as invasive), nor false negatives (i.e., invasive species categorized as non-invasive). Conversely, if the AUC is equal to 0.5 (i.e., the ROC 'curve' is a diagonal line from 0.0 to 1.1$)$, then the test is $0 \%$ accurate as it cannot discriminate between true positives (i.e., actual invasive species) and true negatives (i.e., actual non-invasive species). Typically, the AUC will range between 0.5 and 1.0, and the closer the AUC to 1.0 the better the ability of FISK to differentiate between invasive and non-invasive species. ROC analysis was implemented with package 'pROC' for $\mathrm{R}^{* *}$ using the 2000 default bootstrap replicates (DeLong et al. 1988).

The best FISK threshold, that is the cut-off value that maximizes the probability of correct classification of a species as invasive whilst minimizing that of incorrect classification as non-invasive, was determined using both Youden's $J$ statistics (Youden 1950) and the method of DeLong (DeLong et al. 1988). Youden's index $J$ captures the performance of the ROC analysis and is calculated as:

$$
J=\max \{\text { Sensitivity }+ \text { Specificity }-1\}
$$

and it is the probability of an informed decision, as opposed to a random guess. Whereas, the DeLong method is an exact means to evaluate asymptotically the uncertainty of an AUC by determining the point closest to the top-left part of the plot with perfect sensitivity or specificity. It is typically faster than bootstrapping and pROC will choose the DeLong method by default whenever possible. Optimality criteria for threshold were modified as proposed by Schisterman et al. (2005) and Perkins and Schisterman (2006).

Table 2

FISK assessment of particular nominal species and strains (mtDNA haplotypes) of trout (Salmonidae) alien for streams holding brown trout stocks in Serbia

\begin{tabular}{|c|c|c|c|c|c|c|c|c|c|c|c|c|c|c|c|c|}
\hline \multirow[t]{2}{*}{ Species or strain } & \multirow{2}{*}{ HPL } & \multirow{2}{*}{ INV } & \multirow{2}{*}{ IUCN } & \multicolumn{2}{|c|}{$\begin{array}{l}\text { Score \& } \\
\text { Outcome }\end{array}$} & \multicolumn{3}{|c|}{ Score partition } & \multicolumn{4}{|c|}{ Questions answered } & \multicolumn{3}{|c|}{ Sector affected } & \multirow{2}{*}{$\begin{array}{c}\text { Certainty } \\
\text { Factor }\end{array}$} \\
\hline & & & & OUT & Score & $\mathrm{BIO}$ & UAT & $\overline{\mathrm{ECO}}$ & $\mathrm{BIO}$ & UAT & $\mathrm{ECO}$ & Total & AQA & ENV & NSC & \\
\hline $\begin{array}{l}\text { Oncorhynchus } \\
\text { mykiss }\end{array}$ & $?$ & + & $\mathrm{NE}$ & $\mathrm{H}$ & 30 & 19 & 5 & 6 & 10 & 12 & 24 & 46 & 19 & 21 & 3 & 0.85 \\
\hline Salvelinus fontin & $?$ & + & & MH & 22 & 12 & 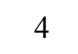 & 6 & 10 & 12 & 24 & 46 & 16 & 20 & 2 & 0.83 \\
\hline Salvelinis alpinus & $?$ & - & $\mathrm{LR} / \mathrm{LC}$ & M & 16 & 12 & 3 & 1 & 10 & 10 & 20 & 40 & 11 & 13 & 2 & 0.85 \\
\hline Salmo trutta & Alcs & + & NDE & $\mathrm{H}$ & 28 & 18 & 7 & 3 & 9 & 11 & 24 & 44 & 16 & 21 & 3 & 0.88 \\
\hline Salmo cf. trutta & Da1 & $\mathrm{n} / \mathrm{a}$ & $\mathrm{LR} / \mathrm{NT}$ & MH & 18 & 11 & 6 & 1 & 8 & 12 & 24 & 44 & 12 & 11 & 3 & 0.83 \\
\hline Salmo cf. trutta & Da2 & $\mathrm{n} / \mathrm{a}$ & $\mathrm{LR} / \mathrm{NT}$ & MH & 20 & 13 & 4 & 3 & 10 & 12 & 24 & 46 & 17 & 15 & 1 & 0.88 \\
\hline Salmo cf. trutta & $\mathrm{Da} 22$ & $\mathrm{n} / \mathrm{a}$ & $\mathrm{LR} / \mathrm{NT}$ & $\mathrm{M}$ & 7 & 3 & 3 & 1 & 7 & 12 & 24 & 43 & 4 & 6 & 1 & 0.87 \\
\hline Salmo macedonicus & Adcs1 & - & DD & MH & 22 & 15 & 4 & 3 & 10 & 12 & 24 & 46 & 17 & 15 & 3 & 0.87 \\
\hline Salmo farioides & Adcs11 & - & $\mathrm{NE}$ & M & 9 & 4 & 4 & 1 & 8 & 12 & 24 & 44 & 5 & 8 & 1 & 0.85 \\
\hline Salmo farioides & Ad-Prz & - & $\mathrm{NE}$ & M & 6 & 5 & 2 & -1 & 8 & 11 & 22 & 41 & 4 & 7 & 0 & 0.91 \\
\hline Salmo letnica & Ad, ? & - & DD & MH & 18 & 14 & 3 & 1 & 10 & 12 & 23 & 45 & 7 & 14 & 3 & 0.80 \\
\hline
\end{tabular}

$\mathrm{HPL}=$ haplotype, $\mathrm{INV}=$ A priori invasiveness, $\mathrm{IUCN}=\mathrm{IUCN}$ status (Anonymous 2014), $\mathrm{OUT}=$ user defined outcome, $\mathrm{BIO}=$ biogeography, $\mathrm{UAT}=$ undesirable attributes, $\mathrm{ECO}=$ biology/ecology, $\mathrm{AQA}=$ aquacultural, $\mathrm{ENV}=$ environmental, $\mathrm{NSC}=$ nuisance; $?=$ unknown haplotype; $+=$ invasive,$-=$ non-invasive, $\mathrm{n} / \mathrm{a}=$ not available yet but considered invasive for the purpose of $\mathrm{ROC}$ analysis; $\mathrm{DD}=$ data deficient, $\mathrm{LR}=$ lower risk, $\mathrm{LC}=$ least concern, $\mathrm{NT}=$ near threatened. $\mathrm{NE}=$ not evaluated; $\mathrm{H}=$ high sensu stricto, $\mathrm{MH}=$ medium high, $\mathrm{M}=$ medium. 
As each response in FISK for a given species is allocated a certainty score $(1=$ very uncertain, 2 = mostly uncertain, $3=$ mostly certain, $4=$ very certain), a 'certainty factor' (CF) was computed as:

$$
\left.\sum\left(\mathrm{CQ}_{i}\right) \cdot(4 \cdot 49)^{-1}\right](i=1, \ldots, 49)
$$

where $\mathrm{CQ}_{i}$ is the certainty for question $i, 4$ is the maximum achievable value for certainty (i.e., 'very certain'), and 49 is the total number of questions comprising the FISK tool. The CF therefore ranges from a minimum of 0.25 (i.e., all 49 questions with certainty score equal to 1 ) to a maximum of 1 (i.e., all 49 questions with certainty score equal to 4$)$.

\section{RESULTS}

Contrary to expectation based on previous findings for the Jerma River, restriction analysis with two endonucleases revealed that trout in that river belong to three phylogenetic lineages (i.e., Adriatic, Danubian, and Atlantic) identified by Bernatchez et al. (1992) (Fig. 2). D-loop sequencing revealed that four of eleven trout were of the Adcs1 haplotype, whereas one of the eleven trout individuals analysed was of the Da22 haplotype and three of them of the Atcs1 haplotype. The sample also held three trout of the Da1 haplotype, most likely a native individual from the catchment.

FISK assessment of eleven introduced and translocated nominal trout species and haplotype strains resulted in scores ranging from 6 (Adriatic trout of the Ad-Prz haplotype) to 30 (rainbow trout; Table 2; Appendix 1). The AUC for the ROC curve (Fig. 3) was 0.7667 (0.3375-0.8014 95\% $\mathrm{CI})$, hence proving the ability of FISK to distinguish reliably between non-invasive and invasive trout species. ROC analysis revealed eight actually positive and three actually negative (i.e., brown trout of haplotypes Da1 and Da22; Macedonian trout of haplotype Adcs1) occurrences out of

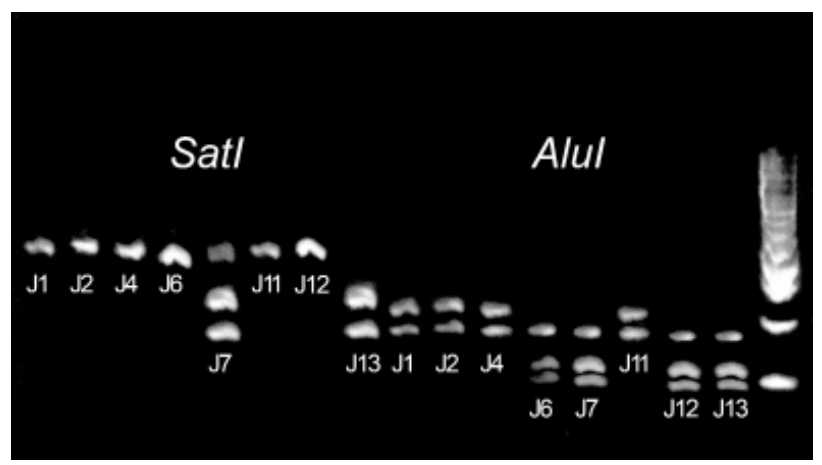

Fig. 2. Electrophoretic image of RFLP analysis of the Control Region in trout from the Jerma River using the SatI (on the left half) and AluI (on the right half of the gel) endonucleases; Two bands from the restriction using SatI endonuclease reveal that trout denoted J7 and J13 on their mtDNA haplotype belong to the Atlantic lineage, whereas a "slower" band (or only two of them in total) in trout denoted $\mathrm{J} 1, \mathrm{~J} 2, \mathrm{~J} 4$, and $\mathrm{J} 11$ from the restriction using AluI endonuclease reveals they hold a haplotype of the Adriatic lineage

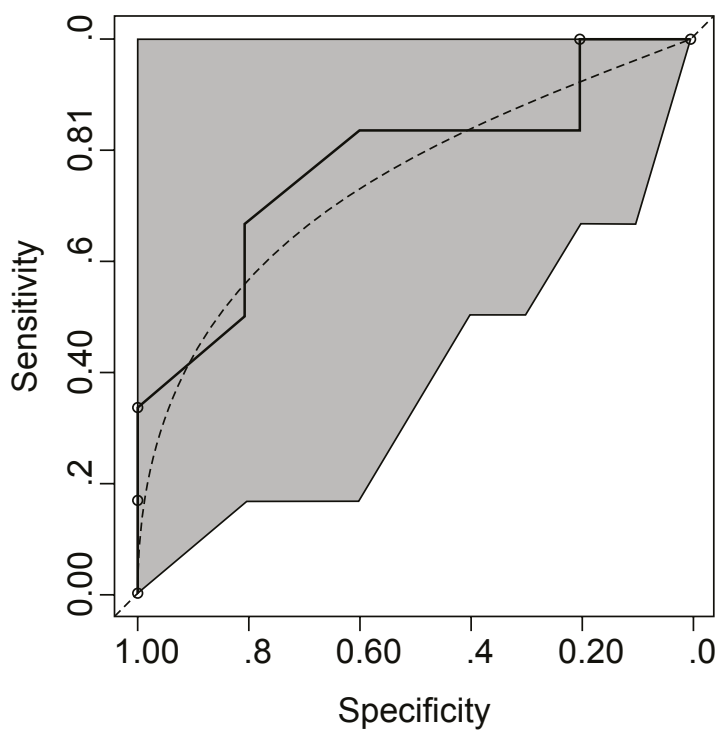

Fig. 3. Fitted (dashed line) and empirical (solid line) Receiver Operating Characteristic (ROC) curve for eleven alien trout species and strains from the ROC Analysis (Lower and Upper 95\% Confidence Intervals of Sensitivity shown in grey)

the eleven trout species and strains assessed. The threshold value of 19 generated by both Youden's and DeLong methods was used to distinguish between "medium risk" trout species and strains with the FISK scores within the interval $[1,19$ [, and "high risk sensu lato" trout species within the interval $[19,57[$ (Fig. 3). The latter were further categorized (after Britton et al. 2010) as "moderately high risk" (interval [19, 25[), except rainbow trout and Atlantic brown trout, who were categorized as "high risk sensu stricto" (interval $[25,30[)$ category. Finally, there were no trout species or strains classified as either "low risk" or "very high risk", i.e., a scores in the intervals $[-15,1[)$ and $[30,57]$, respectively (Table 2). The mean certainty in assessor responses for all species was $3.49 \pm 0.031 \mathrm{SE}$ (i.e., above the category 'mostly certain'), and the mean CF was $0.85 \pm 0.010 \mathrm{SE}$.

Overall, six trout species and strains were regarded as medium risk, and five of them as high risk sensu lato (Fig. 4). In the latter group, rainbow trout and brown trout of the Atlantic strain were categorized as high risk sensu stricto. These were followed by brook trout, Macedonian trout and brown trout Da2 haplotype which achieved the highest scores in trout from the group of medium-high risk category. The assessment criterion that contributed the majority to the high-score records for these trout species and strains was Biogeography, whilst traits of Biology/Ecology and Aquaculture and Environmental sectors were mostly responsible for the differences between those categories.

\section{DISCUSSION}

Balkans (including Serbia) holds native brown trout stocks with numerous taxa and strains that are still not explained in taxonomical sense, but which doubtlessly reveal the prominent diversity of this group of fishes. Invasiveness assessment in such areas is difficult to achieve. In this respect, the ability of brown trout strains to interbreed 


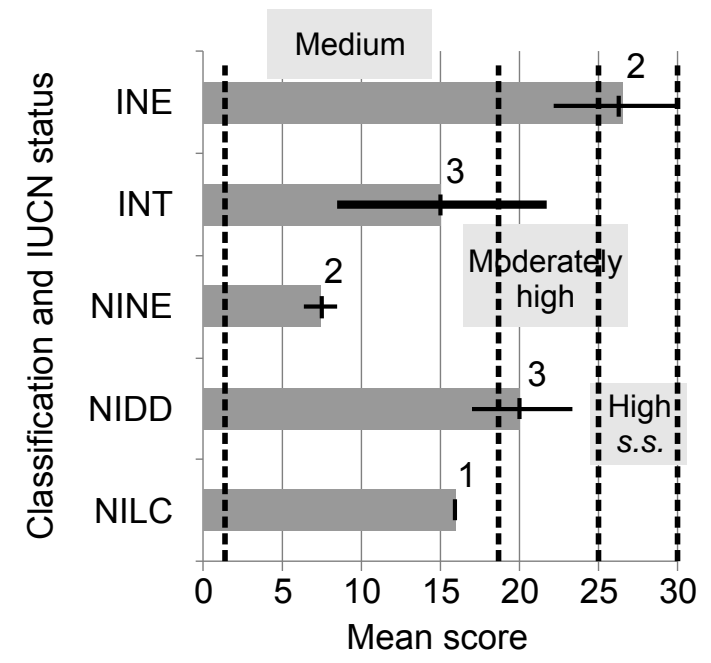

Fig. 4. Mean scores ( \pm standard error and $n$ ) for eleven trout species and strains assessed by FISK in Serbia and categorized according to their a priori assigned invasiveness and conservation status (Table 2); Thresholds are: $<1$ (Low risk) and $\geq 19$ (High risk), with Medium risk trout species and strains in between; Risk categories are: Low $=[-15,1[$, Medium $=[1,19[$, High sensu lato $=[19,57]$; Subcategories in the category High sensu lato: Moderately high $=[19,25[$ and High sensu stricto $=[25,30[$ are here in concern (none of species was categorized into the highest one, Very high $=[30,57]$ )

is well documented. Given the absence of reproductive isolation between distant brown trout strains, molecular markers facilitate the tracing of introgression of genetic material of stocked strains into the native wild brown trout stocks. Until a resolution of the taxonomic ambiguity of brown trout species complex in the Balkans is achieved, it is argued that native (= wild) stocks of brown trout and related trout species can be investigated in conservation and fishery studies based on independent concept of the Evolutionary Significant Unit (ESU) of Crandal et al. (2000) and Fraser and Bernatchez (2001). That concept recognizes the uniqueness (in terms of genetic differentiation) of any population valuable enough to deserve distinct status and conservational efforts required for its preservation. Notably, this conservation practice in trout management has already been applied in Norway, Denmark, and Finland (Taylor and Lightfoot 2003).

Despite the possibility of distinguishing brown trout of Da lineage from that of At lineage on coloration pattern (Fig. 5), it is not possible to distinguish positively on sight particular haplotypes within lineages, or hybrids. Therefore, the discovery of alien brown trout strains had to wait for their detection by molecular methods. Many streams and rivers holding brown trout attractive for fishing were subject to a "put-and-take" fisheries management. It was accomplished by heavy stocking with the hatchery-reared, domesticated and usually non-native brown trout strains. The earliest introduction of the Lake Ohrid trout dates from late 1950s (Janković and Raspopović 1960). The last recorded introduction and translocation of brown trout strains of the Atcs1 and Da2 mtDNA haplotypes, respectively into wild brown trout stocks of Serbia were accomplished by stocking in the period 2000-2003 (Simonović et al. unpublished"). Recent screening revealed further stocking introduced Atlantic and Danubian brown trout of Atcs1 and Da22 mtDNA haplotypes into Jerma River. Stocked strains of trout accompanied alien Macedonian trout of the Adcs1 mtDNA haplotype. Few survivors of Danubian brown trout of the native Da1 mtDNA haplotype were also detected in the Jerma River. Occurrence of brown trout of alien haplotype Da22 that is native in very distant areas of Western Balkans (Škraba et al. unpublished) and Austria (Duftner et al. 2003) supports the conclusion about the unrecorded stocking events.

Application of the FISK protocol (Copp et al. 2005) on alien and translocated trout species and strains of brown trout in Serbia (Table 2, Appendix 1) revealed that highly domesticated rainbow trout and brown trout of Atcs1 haplotype have the greatest potential for invasiveness, followed by brook trout and brown trout of the $\mathrm{Da} 2$ haplotype. Those results deviate from the results of assessment presented in Simonović et al. (2013). Discrepancy between the results of two assessments accomplished in the short time period came both from more narrow scope of this assessment in compare to the previous one and from new facts learnt in the meantime about the naturalization of rainbow trout, brook trout and Arctic charr in the Balkans. The new data covered such countries as Montenegro (Danilo Mrdak personal communication), Croatia (Marina Piria personal communication), Slovenia (Povž and Gregori 2014), Bulgaria and Greece (Apostolos Apostolidis personal communication). New data are also available on the plasticity of life-history traits of Lake Ohrid trout, and the wider dispersal area of brown trout of the Atlantic lineage in Serbia (Table 1).

Justification for the distinct assessment of trout species and strains comes from the narrow and specific ecological demands and habitats to which this natural group of fishes is confined. That more narrowly focused assessment decreased the range of scoring, in compare to the range obtained by screening all alien fish species in the assessment area (Simonović et al. 2013). Such assessment resulted in distribution of invasiveness scores different from that obtained assessing all alien fish species in particular assessment area. Change in distribution of invasiveness scores impacted the calculation of the threshold value, which remarkably rose in compare to the one ascertained previously. The reliability of the new threshold value is proved by the same value on its calculation using both (Youden's statistics and DeLong method) available approaches. The higher new threshold value had an influence on the change of the actual invasiveness status for individual alien trout species and strains. The raise of risk of invasiveness in compare to that assessed in Simonović et al. (2013) was ascertained for particular trout species, e.g., from medium high to high sensu stricto for rainbow trout, from medium to medium high for 

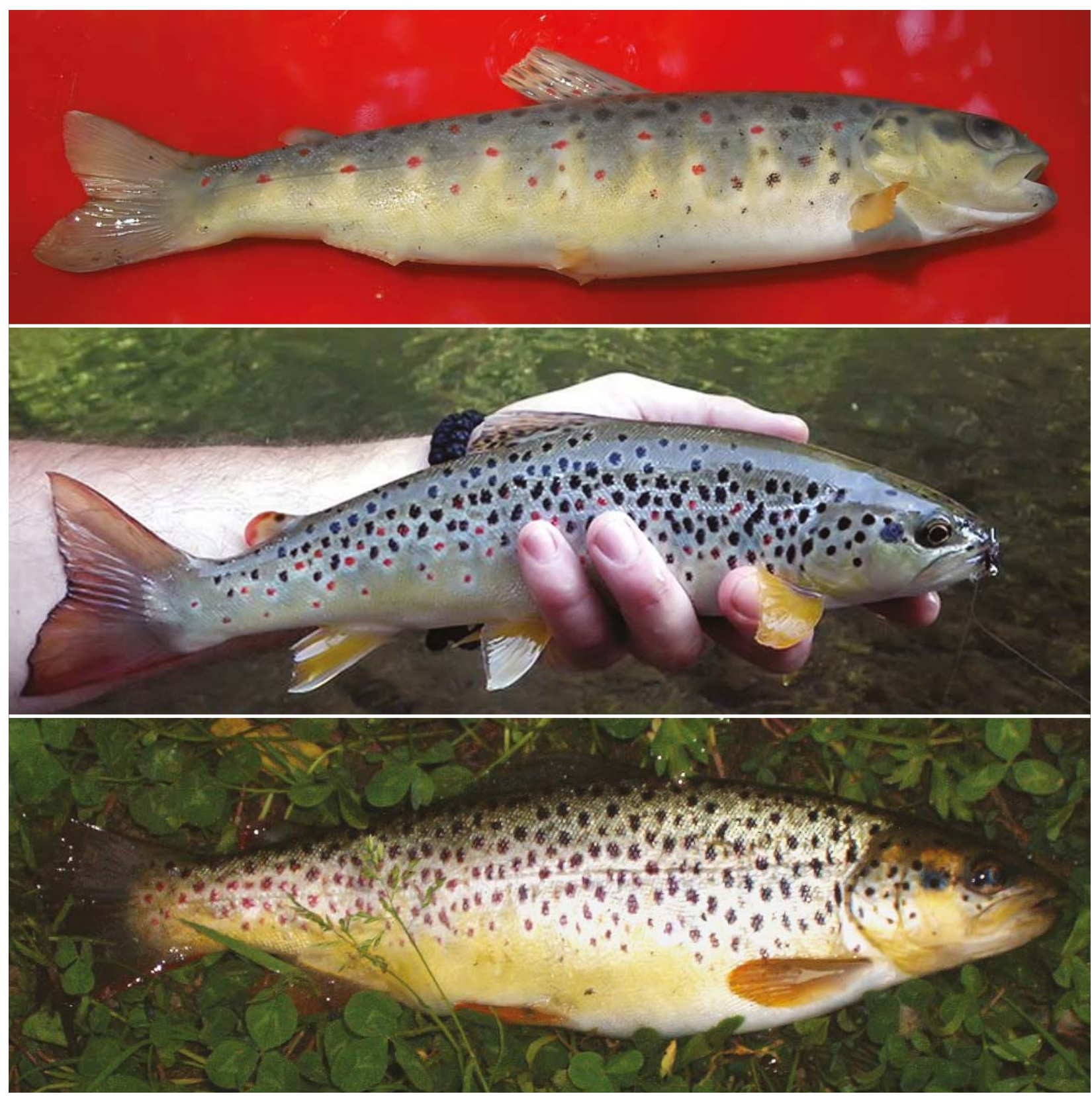

Fig. 5. Overall appearance of brown trout of Danubian- (top), Atlantic- (middle), and Adriatic- (i.e., Macedonian trout) mtDNA lineages in streams of Serbia; Typical brown trout of Danubian lineage have sparse and moderate-to-tiny black spots on back and sparse bright-red ones on flanks; Typical brown trout of Atlantic lineage have only few moderate bright-red spots on back and flanks, and dense and large black spots on flanks and head that form almost regular reticulate pattern in large adult fish; Typical Macedonian trout of Adriatic lineage have very large, deeply dark-purple spots; The basic body colour in all three lineages can vary greatly

brook trout, from low to medium high for Arctic charr, from medium high to high sensu stricto for brown trout of Atlantic strain and from medium to medium high for Ohrid trout. Their domestication in aquaculture and massive production for marketing and stocking purposes augment the impact that alien (e.g., rainbow and brook trout) and translocated, hatchery-produced trout (e.g., Ohrid trout) and brown trout strains already have, or might have to the wild stocks of brown trout. This impact is favoured by their climate matching which made them scoring highly in the category of Biogeography, as well as by their similarity in environmental demands and by their plasticity of life-history in the ecosystem that originally was occupied exclusively by wild brown trout strains, which both lead to the high scoring in the Environmental sector affected (Table 2, Appendix 1).

Gowan and Fausch (1996), Peterson and Fausch (2003), and Kennedy et al. (2003) showed that non-native brook trout are potent invaders, because they have flexible life histories and high growth rate of populations. Fausch (2007) notified the FAO FIGIS data base announced that rainbow, brook and brown trout hold third, 12th, and 13th place in their list of the most widely introduced fish species, since they have been introduced into 97, 49, and 42 countries worldwide, respectively (Welcomme 1992). Because of 
their effect to the native fish fauna, the World Conservation Union Global Invasive Species Program listed rainbow and brown trout as among 100 World's Worst Invasive Alien Species (Lowe et al. 2004). That imposes the ultimate precaution in handling with alien trout species and strains in Serbia and justifies the prohibition of stocking with alien fish species already issued in the Fishery Act (Anonymous 2014a). Since water temperatures suitable for brown trout are also suitable for rainbow trout (Coutant 1977), it is to expect that rainbow trout, especially where heavily stocked over the decades, might eventually establish in recipient trout streams, as occurred in Slovenia (Povž and Gregori 2014). In contrast to certain fisheries in the region, stocking of trout streams with rainbow trout in Serbia was very limited. Recently, rainbow trout recorded in trout streams are only feral ones that escape from trout farms.

Arctic char was introduced into the Kokin Brod Reservoir (Sava River drainage, Black Sea Basin) about three decades ago, and now it is an important angling fish there. Despite reported introduction into the Lisina Reservoir (Dragovištica River drainage, Aegean Sea basin), there are no records about its establishment. Apparently, its spreading and acclimatization depends on stocking.

The introgression of alien Atcs1 and translocated Da1 and Da2 strains into the gene pool of wild brown trout in the recipient headwater streams without any effective control increases the risk for their establishment, as revealed for the Gradac (Simonović et al. 2014) and Jerma rivers (this paper), as well as for the middle Danube River in the areas upstream of (Marić et al. 2012) and within the Đerdap Gorge (Iron Gate) area (Tošić et al. unpublished). In contrast to Atlantic brown trout stocked into the River Gradac that were introduced from Bosnia and Herzegovina in 2000, it is not possible to determine the origin of Atlantic brown trout occurring in the Danube River. Likewise, the origin of brown trout hatchery reared stocking material of the Da1 and Da2 haplotypes recorded in the Crni Timok drainage area (Tošić et al. 2014) also remained unknown, so far.

Macedonian trout of the domesticated Adcs1 haplotype was stocked both into the Lisina Reservoir and into the lower section of the Jerma River (Marić et al. 2006a) for fishery purposes. It spread upstream into headwaters and easily naturalized there.

It seems that originally lacustrine Ohrid trout easily acclimatizes to stream-dwelling life style, due to its plasticity. Its late autumn and winter spawning season matches that of wild, stream-dwelling native brown trout (Zoran Spirkovski personal communication). Although there are no available records about its introgression into the native, wild brown trout stock, the easy domestication and availability at the hatchery in the Hydrobiological Institute in Ohrid impose the permanent risk of transfer into new waters.

The invasiveness potential of brown trout of the Da22 haplotype, of Macedonian trout of the Adcs11, and of Adriatic trout of the Ad-Prz haplotypes was assessed as moderate. That was mainly due to their narrow dispersal area, isolation from other brown trout stocks, and lack of data about any kind of impact they might have. The closest known area with brown trout of the Da22 haplotype is the upper Una
River in western Bosnia ( ̌́kraba et al. unpublished). Stocking of streams in Southern Serbia with Adriatic trout native to headwaters of the Beli Drim River in Metohia (Marić et al. 2006a) is to be considered a single case with no longterm events, as yet.

Uncontrolled introductions and translocations of non-native trout species and strains of brown trout do not impact only the original diversity, but also the original genetic structure of wild trout populations by introgression, as revealed both worldwide (Laikre and Ryman 1996, Laikre et al. 1999) and locally (Marić et al. 2006b, Razpet et al. 2007, Simonović et al. 2014, Tošić et al. 2014). Decrease in the amount of the intraspecific diversity, i.e., heterozygosity was recorded both in North America (White 1989) and Europe (Ryman et al. 1995, Laikre and Ryman 1996, Ferguson 2006). In addition, the possibility of hybridization between the stocked-, hatchery reared-, and native brown trout led to the loss of the co-adapted gene complexes created through the long-term adaptation of aboriginal brown trout strain in its native habitat (Templeton 1986). Several kinds of impact by stocked brown trout strains on the native ones were recognized also in the UK (Anonymous 2003b), e.g., competition and predation by stocked fish (Nehring 1993), stimulation of influx of predators, stimulation of fishing effort and thus an excessive exploitation of wild stocks (Frost 1974), introduction of diseases (Nehring et al. 1998), and change in genetic composition of wild stocks due to interbreeding (Hansen 2002). The better fitness, faster growth, and earlier maturation (features being considered "enhancing" by common brown trout fisheries management practice) of stocked alien strains of brown trout due to greater versatility for various environmental conditions might also augment the loss of original diversity of wild brown trout.

That happened in the drainage areas of the Nišava and Božica rivers, where alien trout spread rapidly throughout the drainage area, though by two different mechanisms. In the Nišava River drainage area, downstream spreading of alien trouts was facilitated by release of the cold hypolimnial water from reservoirs situated in the middle stretch that improved the water quality of tailwaters, creating the favourable habitat for trouts. The spreading success implies that annual temperature regime, i.e., the growing season degree days (GSDD) of Fausch (2007), was favourable enough to provide adequate recruitment to sustain a population. The invasive effect of Atlantic brown trout and Macedonian trout of the Atcs1 and Adcs1 haplotypes, respectively is obvious from the suppressing of wild brown trout of the Danubian lineage and likely by hybridization with it throughout the middle Nišava River drainage area. The other mechanism has acted in the headwater stretch of the Božica River, which formerly held exclusively wild Ad-Bož haplotype, presumably important for the resolving of the phylogeny of brown trout complex in general (Marić et al. 2006a). It was invaded by stocked Macedonian trout of the Adcs1 mtDNA haplotype from the Lisina Reservoir. Adverse effects that stocking of highland reservoirs with alien trout species and strains makes to the indigenous brown trout stocks strongly ques- 
tion the justification of stocking with them, having in mind the vulnerability of native trout stocks in headwater sections upstream of reservoirs. In Montana, USA, the trout fishery management, that relied on stocking, was abandoned in 1974. That was set after widespread losses of the original west-slope cutthroat trout, Oncorhynchus clarkii (Richardson, 1837), and Arctic grayling, Thymallus arcticus (Pallas, 1776), populations, due to early hatchery introductions of rainbow and brown trout (McMillan 2014). The resilience of the indigenous strains of native trout species to environmental challenges was revealed by Vincent (1979), who showed that streams in Montana were capable of supporting the native, wild trout populations, with no need for hatcheries and necessity of stocking to provide high quality angling opportunities.

The rising impact from recreational fishery on the wild brown trout diversity by stocking imposes the necessity for the conservation of genetic variability inherent to the aboriginal brown trout stocks and preservation of their viability. The need for conservation is even greater concerning the recent climate changes. The majority of brown trout streams in Serbia are already scarce in water, especially during the dry summer period. Many of them are used for water supply of local communities and irrigation. That, together with the pronounced deforestation in headwater areas makes their water regime even harsher, doing wild trout stocks more susceptible to various kinds of threats, including introduction of alien trout species and strains. Balanced water capturing and timber utilization enhance the restoration of habitat, which enables an attainment of maturity in native brown trout at greater body size (Simonović and Nikolić 2007). Improvement of the population structure regarding the increase in age and size (i.e., average individual weight) adds to the resilience of stream-dwelling wild brown trout stocks and raises the fishery attractiveness, as well.

The preservation of the aboriginal diversity of wild brown trout stocks in Serbia that are still not affected by introduction of alien trout strains imposes the actions in trout fishery management that strictly fosters either conditional (i.e., landing regime balanced to the natural production), or unconditional "Catch-and-Release" (C\&R). Several streams in Southern Serbia (Vrla, Džepska, Božička, and Ljubatska rivers and other streams in their vicinity) hold in their headwaters ancestral strains of brown and Macedonian trout (Marić et al. 2006a). They are small freestone creeks, with only small-size, still pure, native trout. The management with streams holding only native trout (Vrla, Džepska, and Ljubatska rivers) would rely on stringent control of the ban of landing (i.e., on the unconditional C\&R) that should be issued. Such way of management allows the fishery utilization with no need for any stocking. That minimizes the risk of introduction of alien trout strains and preserves indigenous trout.

Alternatively, in many highly productive streams with large and numerous brown trout of the aboriginal and exclusive haplotype (e.g., Crni Timok River and its headwaters with Da23c haplotype) (Tošić et al. 2014) that sustain the strong fishing pressure, there is already introduced brown trout of the non-indigenous (e.g., Da1 and Da2 mtDNA) haplotypes. Considering that introduced brown trout are not clearly distinguishable from native ones on sight, Crni Timok River should be stocked heavily and persistently with the 1+ hatchery reared brown trout fry of the native Da23c haplotype that came from the wild, locally adapted brood material, as recommended by Giles et al. (2004). Nehring (1993) showed that it was possible to restore the original rainbow trout stock and to suppress the introduced brown trout in streams in Colorado (USA) by stocking with the locally adapted strain, in combination with issuing of special angling regulations. That stocking material with the sufficient level of heterozygosity (Taylor and Lightfoot 2003) would be able to overcompete brown trout of alien strains, to outnumber and eventually extirpate them.

Easy distinguishing between alien Atlantic and Macedonian trout on the one, and native Danubian brown trout on the other side by bare eye (Fig. 5) enables the compulsory taking out of landed fish of alien trout species. Restoration of native Danubian brown trout stock that involves retaining of landed alien fishes would be more effective in combination with the stocking with native brown trout. Similar management should be applied also in all streams where brown trout of the Atlantic strain were stocked, since it is easy to distinguish them on sight from those of Danubian strains (Fig. 5). The currently fashionable allaround application of the unconditional C\&R in streams and rivers holding the alien brown trout strains should be discouraged by all means during the restoration of the indigenous wild stock. Management that involves the increase of harvest limits of alien trout has already been applied in the Yellowstone National Park in the Wyoming, USA, where every landed rainbow-, lake-, and brown trout must be removed, or killed in waters where they coexist with native cutthroat trout and fluvial Arctic grayling (Anonymous 2013).

Only the brood fish from the locally adapted wild stocks of Danubian brown trout should be used for the restorative purposes. Their wild status should be certified after the issued and enforced procedure for their marking, genotyping and verification of their aboriginality, as in Denmark, Finland, and Switzerland (Taylor and Lightfoot 2003). Assessment of the status of each brood fish is quick and easy by RFLP (Restriction Fragment Length Polymorphism) technique on PCR amplified Control Region (CR) of the mtDNA. The characterization of Danubian, Adriatic, and Atlantic brown trout lineages using AluI and SatI restriction endonucleases that cut Control Region (D-loop) at characteristic profiles of mtDNA (Marić et al. 2006b, Simonović et al. 2014) can provide the preliminary sorting out to lineages. Then, the sequencing of the Control Region of the mtDNA in brood fish that doubtlessly belong to the Danubian lineage would reveal their haplotype. Both activities should be proscribed in the fishery legislative by fisheries authorities. Verification and marking of brood fish used for the restorative purpose should be implemented in the administrative management of trout waters in each registered brown trout hatchery in all catchments in the country. It must be controlled in a due time interval, e.g., before the 
autumn stocking season. Setting of this brood trout assessment system should be initially granted by fisheries authorities. Afterwards, it must be updated on the preparation of the fishery management plans at the each trout catchment. The finances for this are to be provided from the taxes that state fishery administration already collects from the fisheries concessionaires.

\section{ACKNOWLEDGEMENTS}

The paper is supported by Grant 173025 of the Ministry of Education, Science and Technological Development of Serbia.

\section{REFERENCES}

Anonymous 2003. National trout and grayling fisheries strategy. UK Environment Agency, Bristol.

Anonymous 2013. Yellowstone fishing regulations. Yellowstone National Park, USA.

Anonymous 2014a. Zakon o ribarstvu. [Fishery Act.] Službeni glasnik Republike Srbije 128: 6-18. [In Serbian.]

Anonymous 2014b. The IUCN red list of threatened species. Version 2014.1. Downloaded on 26 June 2014. http://www.iucnredlist.org

Bernatchez L. 2001. The evolutionary history of brown trout (Salmo trutta L.) inferred from phylogeographic, nested clade, and mismatch analyses of mitochondrial DNA variation. Evolution 55 (2): 351-379. DOI: $10.1111 /$ j.0014-3820.2001.tb01300.x

Bernatchez L., Guyomard R., Bonhomme F. 1992. DNA sequence variation of the mitochondrial control region among geographically and morphologically remote European brown trout Salmo trutta populations. Molecular Ecology 1 (3): 161-173.

Bewick V., Cheek L., Ball J. 2004. Statistics review 13: Receiver operating characteristic curves. Critical Care 8 (6): 508-512.

DOI: $10.1186 / \operatorname{cc} 3000$

Britton J.R., Cucherousset J., Davies G.D., Godard M., Copp G.H. 2010. Non-native fishes and climate change: Predicting species responses to warming temperatures in a temperate region. Freshwater Biology 55 (5): 1130-1141.

DOI: $10.1111 / \mathrm{j} .1365-2427.2010 .02396 . x$

Copp G.H., Garthwaite R., Gozlan R.E. 2005. Risk identification and assessment of non-native freshwater fishes: Concepts and perspectives on protocols for the UK. Science Series Technical Reports No. 129.Cefas, Lowestoft, UK.

Copp G.H., Vilizzi L., Mumford J., Fenwick G.V., Godard M.J., Gozlan R.E. 2009. Calibration of FISK, an invasiveness screening tool for nonnative freshwater fishes. Risk Analysis 29 (3): 457-467.

DOI: 10.1111/j.1539-6924.2008.01159.x

Coutant C.C. 1977. Compilation of temperature preference data. Journal of the Fisheries Research Board of Canada 34 (5): 739-745.

DOI: $10.1139 / \mathrm{f} 77-115$
Crandal K.A., Bininda-Edmonds O.R.P., Mace G.M., Wayne R.K. 2000. Considering evolutionary processes in conservation biology. Trends in Ecology and Evolution 15 (7): 290-295.

DOI: $10.1016 / \mathrm{s} 0169-5347(00) 01876-0$

DeLong E.R., DeLong D.M., Clarke-Pearson D.L. 1988. Comparing the areas under two or more correlated receiver operating characteristic curves: A nonparametric approach. Biometrics 44 (3): 837-845.

DOI: $10.2307 / 2531595$

Duftner N., Weiss S., Medgyesy N., Sturmbauer C. 2003. Enhanced phylogeographic information about Austrian brown trout populations derived from complete mitochondrial control region sequences. Journal of Fish Biology 62 (2): 427-435.

DOI: 10.1046/j.1095-8649.2003.00038.x

Fausch K.D. 2007. Introduction, establishment and effects of non-native salmonids: Considering the risk of rainbow trout invasion in the United Kingdom. Journal of Fish Biology 71 (Suppl. D): 1-32. DOI: $10.1111 / \mathrm{j} .1095-8649.2007 .01682 . x$

Ferguson A. 2006. Genetic impacts of stocking on indigenous brown trout populations. Science Report SC040071/SR. UK Environmental Agency, Bristol.

Frazer D.J., Bernatchez L. 2001. Adaptive evolutionary conservation: Towards a unified concept for defining conservation units. Molecular Ecology 10 (12): 2741-2752. DOI: 10.1046/j.0962-1083.2001.01411.x

Froese R., Pauly D. (eds.) 2014. FishBase. [version 06/2014] http://www.fishbase.org

Frost W.E. 1974. A survey of rainbow trout (Salmo gairdneri) in Britain and Ireland. The Salmon and Trout Association, London, UK.

Giles N., Westgarth J., Hewlett N. 2004. Management advice for trout, grayling and Arctic char fisheries. Fisheries Technical Manual No. 7. UK Environmental Agency, Bristol, UK.

Gowan C., Fausch K.D. 1996. Mobile brook trout in two high-elevation Colorado streams: Re-evaluating the concept of restricted movement. Canadian Journal of Fisheries and Aquatic Sciences 53 (6): 1370-1381. DOI: $10.1139 /$ f96-058

Hansen M.M. 2002. Estimating the long-term effects of stocking domesticated trout into wild brown trout (Salmo trutta) populations: An approach to using microsatellite DNA analysis of historical and contemporary samples. Molecular Ecology 11 (6): 1003-1015. DOI: 10.1046/j.1365-294X.2002.01495.x

Janković D., Raspopović M. 1960. Ohridska pastrmka (Salmo letnica typicus K.) pod promenjenim uslovima u Vlasinskom baražnom jezeru. [Lake Ohrid trout (Salmo letnica typicus K.) under the altered conditions in the Vlasina reservoir.] Arhiv bioloških nauka 12 (3-4): 117-122. [In Serbian.]

Kennedy B.M., Peterson D.P., Fausch K.D. 2003. Different life histories of brook trout populations invading mid-elevation and high-elevation cutthroat trout 
streams in Colorado. Western North American Naturalist 63 (2): 215-223.

DOI: $10.3398 / 064.069 .0116$

Laikre L., Antunes A., Apostolidis A., Berrebi P., Duguid A., Ferguson A., Garcia-Marin H.L., Guyomard R., Hansen M.M., Hindar K., Koljonen M.-L., Largiarder C., Martinez P., Nielsen E.E., Palm S., Ruzzant D., Ryman N., Tryantaphyllidis C. 1999. Conservation genetic management of brown trout (Salmo trutta) in Europe. Report by the Concerted action on identification, management and exploitation of genetic resources in the brown trout (Salmo trutta). (TROUTCONCERT; EU FAIR CT97-3882).

Laikre L., Ryman N. 1996. Effects on intraspecific biodiversity from harvesting and enhancing natural populations. Ambio 25 (8): 504-509.

Lowe S., Browne M., Boudjelas S., Poorter M.D. 2004. 100 of the world's worst invasive alien species: A selection from the Global Invasive Species Database. Invasive Species Specialist Group (ISSG) a specialist group of the Species Survival Commission (SSC) of the World Conservation Union (IUCN), World Conservation Union, Auckland, New Zealand.

Marić S., Hegediš A., Nikolić V., Simonović P. 2004. Conservation status of two eastern Balkan endemic fish species in Serbia and a proposal for their protection. Acta Zoologica Bulgarica 56 (2): 213-222.

Marić S., Nikolić V., Tošić A., Simonović P. 2012. Record of the brown trout Salmo trutta L., 1758 in the main riverbed of the Serbian part of the Danube River. Journal of Applied Ichthyology 28 (1): 135-137.

DOI: 10.1111/j.1439-0426.2011.01881.x

Marić S., Snoj A., Nikolić V., Simonović P. 2006a. Genetic differentiation of trout (Salmo spp.) populations in Serbia ascertained using RFLP technique on PCR amplified control region of mitochondrial DNA. Acta Veterinaria 56 (5-6): 423-430.

DOI: 10.2298/AVB0606423M

Marić S., Sušnik S., Simonović P., Snoj A. 2006b. Phylogeographic study of brown trout from Serbia, based on mitochondrial DNA control region analysis. Genetics, Selection, Evolution 38 (6): 411-430.

DOI: $10.1051 /$ gse:2006012

McMillan B. 2014. To save wild steelhead, get rid of hatcheries. Osprey 79 (1): 1-7.

Nehring R.B. 1993. Stream fisheries investigations: Wild trout introductions. Federal Aid Final Report F-51-R. Colorado Division of Wildlife, Fort Collins, CO, USA.

Nehring R.B., Thompson K.G., Hebein S. 1998. Impacts of whirling disease on wild trout populations in Colorado. Transactions of the North American Wildlife and Natural Resources Conference 63: 82-94.

Perkins N.J., Schisterman E.F. 2006. The inconsistency of "optimal" cutpoints obtained using two criteria based on the Receiver Operating Characteristic Curve. American Journal of Epidemiology 163 (7): 670-675.

DOI: 10.1093/aje/kwj063
Peterson D.P., Fausch K.D. 2003. Upstream movement by nonnative brook trout (Salvelinus fontinalis) promotes invasion of native cutthroat trout (Oncorhynchus clarki) habitat. Canadian Journal of Fisheries and Aquatic Sciences 60 (12): 1502-1516.

DOI: $10.1139 /$ f03-128

Povž M., Gregori A. 2014. Tujerodne sladkovodne ribe v Sloveniji. [Alien freshwater fishes in Slovenia.] Zavod Umbra, Ljubljana. [In Slovenian.]

Razpet A., Marić S., Parapot T., Nikolić V., Simonović P. 2007. Re-evaluation of Salmo data by Gridelli (1936) description of stocking, hybridization and repopulation in the River Soča basin. Italian Journal of Zoology $\mathbf{7 4}$ (1): 63-70.

DOI: $10.1080 / 11250000601090081$

Richardson D.M., Pyšek P., Rejmánek M., Barbour M.G., Panetta F.D., West C.J. 2000. Naturalization and invasion of alien plants: Concepts and definitions. Diversity and Distribution 6 (2): 93-107. DOI: $10.1046 / j .1472-4642.2000 .00083 . x$

Ryman N., Utter F., Laikre L. 1995. Protection of intraspecific biodiversity of exploited fishes. Reviews in Fish Biology and Fisheries 5 (4): 417-446.

DOI: $10.1007 / \mathrm{BF} 01103814$

Schisterman E., Perkins N.J., Liu A., Bondell H. 2005. Optimal cut-point and its corresponding Youden Index to discriminate individuals using pooled blood samples. Epidemiology 16 (1): 73-81.

DOI: 10.1097/01.ede.0000147512.81966.ba

Simonović P., Marić S., Nikolić V. 2005. Morphological differentiation of salmonines (subfamily Salmoninae) with emphasis on trout Salmo spp. stocks in Serbia and adjacent regions. Acta Zoologica Bulgarica 57: 341-362.

Simonović P., Marić S., Nikolić V. 2007. Trout Salmo spp. complex in Serbia and adjacent regions of western Balkans: Reconstruction of evolutionary history from external morphology. Journal of Fish Biology 70 (Suppl. C): $359-380$. DOI: $10.1111 / \mathrm{j} .1095-8649.2007 .01516 . \mathrm{X}$

Simonović P., Mrdak D., Tošić A., Škraba D., Grujić S., Nikolić V. 2014. Effects of stocking with brood fish to manage resident stream dwelling brown trout Salmo cf. trutta L. stock. Journal of Fisheries Sciences 8 (2): 139-152.

DOI: $10.3153 /$ jfscom. 201418

Simonović P.D., Nikolić V.P. 2007. Density-dependence of growth characteristics and maturation in stream-dwelling resident brown trout, Salmo trutta, in Serbia. Fisheries Management and Ecology 14 (1): 1-6.

DOI: $10.1111 /$ j.1365-2400.2006.00517.x

Simonović P., Tošić A., Vassilev M., Apostolou A., Mrdak D., Ristovska M., Kostov V., Nikolić V., Škraba D., Vilizzi L., Copp G.H. 2013. Risk assessment of non-native fishes in the Balkans region using FISK, the invasiveness screening tool for non-native freshwater fishes. Mediterranean Marine Science 14 (2): 369-376. DOI: $10.12681 / \mathrm{mms} .337$ 
Taylor J., Lightfoot G. 2003. National trout and grayling fisheries strategy. Brown trout rearing and stocking in Europe and North America-policies and practices. Environmental Agency, HO-08/03-5K-BHMC-SP-WM094.

Templeton A.R. 1986. Coadaptation and outbreeding depression. Pp. 105-116. In: Soulé M.E. (ed). Conservation biology. The science of scarcity and diversity. Sinauer Associates, Sunderland, MA, USA.

Tošić A., Škraba D., Nikolić V., Mrdak D., Simonović P. 2014. New mitochondrial DNA haplotype of brown trout Salmo trutta L. from Crni Timok drainage area in Serbia. Turkish Journal of Fisheries and Aquatic Sciences 14 (1): 37-42.

DOI: 10.4194/1303-2712-v14_1_05
Vincent D. 1979. Madison River, the: What does the future hold? Montana Outdoors 10 (4): 31-33.

Welcomme R.L. 1992. A history of international introductions of inland aquatic species. ICES Marine Science Symposium 194 (1): 3-14.

White R.J. 1989. We're going wild: a 30-year transition from hatcheries to habitat. Trout Special Anniversary Series: 15-49.

Youden W.J. 1950. Index for rating diagnostic tests. Cancer 3 (1): 32-35.

DOI: 10.1002/1097-0142(1950)3:1<32::AID-CNCR2820030106>3.0.CO;2-3

Received: 1 December 2014 Accepted: 5 April 2015

Published electronically: 30 June 2015 


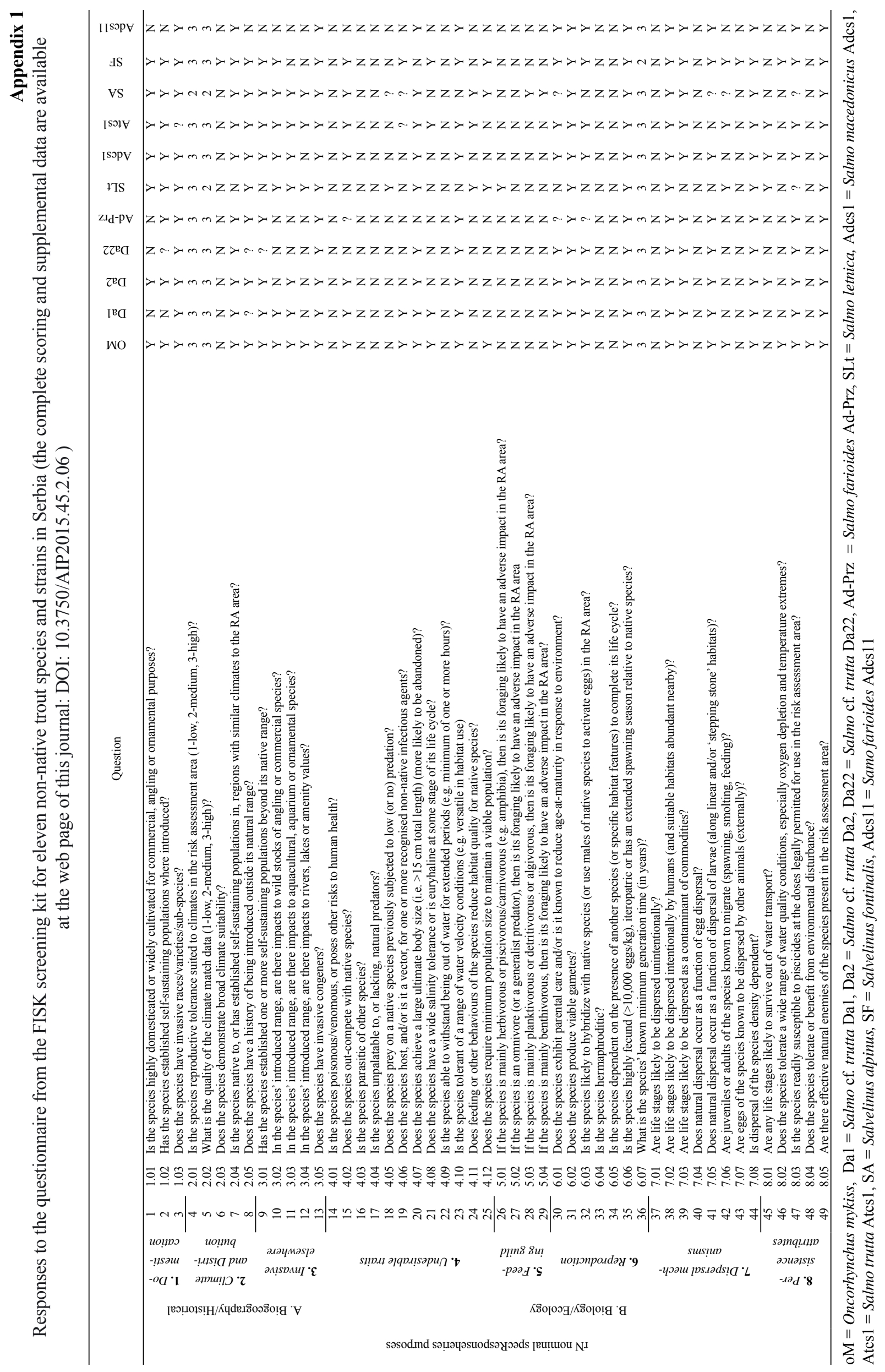

